
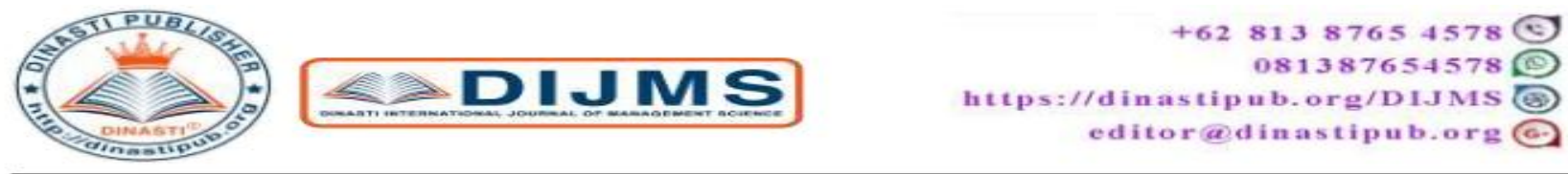

Volume 1, Issue1, September2019

E-ISSN : 2686-522X

P-ISSN : 2686-5211

\title{
THE EFFECT OF MARKETING STRATEGY AND COMMUNITY PERCEPTION OF DECISIONS TO CHOOSE ISLAMIC JUNIOR HIGH SCHOOL IN JAMBI PROVINCE
}

\author{
Mahmud \\ Lecturer of Sulthan Thaha Syaifuddin State Islamic University, Jambi Indonesia
}

\begin{tabular}{|c|c|}
\hline $\begin{array}{l}\text { ARTICLE INFORMATION } \\
\text { Received : 01/09/2019 } \\
\text { Revised : 11/09/2019 } \\
\text { Issued: } 21 / 09 / 2019\end{array}$ & $\begin{array}{l}\text { Abstract: This study aims to analyze the effect of } \\
\text { Marketing Strategy and Community Perception on the } \\
\text { Decision of Choosing Islamic Junior High School in } \\
\text { Jambi Province both partially and simultaneously. The } \\
\text { population in this study is the community who send their } \\
\text { children to private Tsanawiyah Madrasahs in Jambi } \\
\text { Province representing } 3 \text { regions with } 178 \text { people. } \\
\text { Quantitative analysis method using path analysis, } \\
\text { followed by analysis of determination (R Square), partial } \\
\text { hypothesis testing (t test) and simultaneous (F test) with } \\
\text { alpha } 5 \text { percent (0.05). Before further analysis, the } \\
\text { analysis requirements test is carried out first. Analysis } \\
\text { tools using SPSS Version } 21.0 \text { for Windows. The results } \\
\text { showed that marketing strategies and public perceptions } \\
\text { had a positive and significant effect on the decision to } \\
\text { choose Islamic Junior High School in Jambi Province. } \\
\text { Keywords: Marketing Strategy, Community Perception, } \\
\text { Choosing Decisions. }\end{array}$ \\
\hline
\end{tabular}

\section{INTRODUCTION}

The existence of management in an institution is very important. Because in management it covers all aspects of management and regulation in an institution, especially education institutions in which there are many people. Educational institutions such as madrasa educational institutions is a formal institution that is very strategic to develop thinking (science), opinions and most importantly is to be able to develop and improve human resources (student resources) itself optimally. Educational institutions Islamic School also consists of a collection of intelligent beings, such as school principals, education staff (Teachers), education staff (administrators), students (students) and even to the school guards (security). All of them are united to build their institution into a professional, advanced and developing educational institution.

Developing educational institutions is one of the main tasks and responsibilities of the head of the Islamic School as a manager. The task must be carried out optimally, planned and 
directed by the head of the madrasa and by the education staff in the school (Machalli, 2016: 110). Because if the educational institution develops, advances and is famous, then the school will be glimpsed and in demand by many people (society). And of course it will affect the in-put madrasa. A lot of input is one indicator that the islamic school is progressing and developing. According to Mulyasa (2011: 50) the development of educational institutions is also inseparable from the role of the head of the islamic school and management of school relations with the community. Schools and communities have a very close relationship in achieving school or educational goals effectively and efficiently.

In addition, the head of the Islamic school must also be able to utilize the existing human resources in the school, and how to make the students in the islamic school have achievements that can boast and make school proud, both at the local, national and national levels. international, so that Islamic school became the target and even became a choice for the community, and then in the end the community or parents decided their choice at the Islamic Junior High School.

The decision to choose is not an easy matter. The decision to choose a very heavy job. Because if one chooses, it will affect someone. What's more to choose a school / islamic school that will entrust their children for three years with a myriad of hopes. According to Terry (2011: 34) decision making is to choose alternatives from two or several alternatives that exist to determine the direction of the goal to be achieved. These alternatives can be in the form of a physical condition, or creative endeavors, or a place to gather thoughts, feelings, creative efforts or a place to gather thoughts, feelings and knowledge to carry out an action.

Development and improvement of educational institutions (schools), there needs to be an educational marketing services strategy that can answer the challenges, developments and changes and progress of the current era. Marketing in the context of educational services is a social and managerial process to get what is needed and wanted through the creation of offers, exchanges of valuable products with parties in the field of education (Alma, 2003: 2). When educational institutions have become an economic institution, competition between institutions is unavoidable. To be strong in facing these challenges and competition, the role of marketing strategy is needed so that the educational institution still exists in the midst of today's tight competition.

A quality marketing strategy, which can be accounted for and has even been able to influence people, this will change people's perceptions. Public perception is very dependent on the information they receive. Marketing strategy is one way to convey a message to a product to the wider community. The product intended here is related to educational information. Like talking about the advantages found in educational institutions. All excellence in the institution must be packaged in such a way that it becomes an appropriate product to be sold to the wider community. For this reason, marketing marketing services must have a mature strategy so that it can shape people's perceptions.

Schiffman and Kanuk in Mulyadi (2011: 66) say that perception is described as the process by which a person's individual selects, organizes and translates stimulation into a coherent meaning with all the occurrences of the world. Community perceptions will depend on what is seen, information obtained about the madrasa will be used as an option for their sons and daughters. If the perception of the madrasa is good, it can be ascertained that the choice falls on the madrasa, but if the perception is negative, then it will certainly affect the decision.

This research was conducted with the aim of analyzing: 
1) The influence of marketing strategies on decision making;

2) The effect of people's perception on the decision to vote; and

3) The effect of marketing strategy and people's perception simultaneously on the decision to choose.

\section{LITERATURE REVIEW \\ Decision to Choose}

Decisions are the result of solving a problem that must be dealt with firmly by anyone and anywhere. In the Great Dictionary of Science, decision making is defined as the choice of decisions or policies based on certain criteria. According to Reason in Dagun (2006: 185) decision making can be considered as an outcome or output from mental or cognitive processes that lead to the selection of an action pathway among several available alternatives.

According to Terry (2012: 34) decision making is the selection of certain alternative behavior from two or more alternatives that exist to determine the direction of the goal to be achieved. Furthermore Terry (2012: 34) suggests that these alternatives can then be in the form of a physical condition, or creative endeavors, or a place to gather thoughts, feelings and knowledge to carry out an action.

According Sudaryono (2016: 102) in the decision making process begins with the needs that are trying to be met. This fulfillment is related to several alternatives, so an evaluation is needed to obtain the best alternative from consumers' perceptions. The process of making a decision is indeed a choice made with care, let alone choosing a school that we make as a place to gain knowledge.

According to Herbert Simon in Siswanto (2012: 272) propose a useful model as a basis in the decision-making process, namely: 1) Research, namely studying the environment for conditions that require decisions, raw data obtained, processed and tested to act as a direction that can identify problem; 2) Design, i.e. registering, developing and analyzing possible directions of action. This activity includes the process of understanding problems, producing solutions, and testing the feasibility of the solution; and 3) Election, which is to determine the direction of a particular action from the whole, the choice is determined and implemented.

Gibson in Siswanto (2012: 175) argues that the decision making process consists of seven stages. 1) Establishing specific goals and measuring results; 2) Identification of problems; 3) Development of alternatives; 4) Evaluation of alternatives; 5) Alternative selection; 6) Implementation of decisions; and 7) Control and evaluation.

\section{Marketing strategy}

According to Kotler (2003: 103) distinguishes the definition of marketing into two aspects, namely social and managerial aspects. The definition in the social aspect is more directed at the marketing procedures used in society, where a marketer calls this a procedure to "provide a higher standard of living.

Marketing strategy consists of analysis, strategy development, and its implementation in developing a vision of the level of market interest in the organization, market selection strategies, target market selection, and development, implementation, and management of positioning and marketing strategy programs designed to find the value desired by consumers in every targeted market. Marketing strategy is a strategy to serve the market or market segment that is targeted by 
the company. The definition of marketing strategy is the marketing logic used by companies in the hope that business units can achieve company goals.

According to Radiosonu (2006: 27) in designing a competitive marketing strategy begins by analyzing competitors. Companies compare customer value and satisfaction with the value provided by products, prices, promotions and distribution to nearby competitors. Radiosunu (2006: 27) further explained that marketing strategies are based on the following five strategic concepts: a) market segmentation, each market consists of various buyers who have different needs, buying habits and reactions. The company cannot possibly meet the needs of all buyers. Therefore companies must group heterogeneous markets into homogeneous market units; b) market positioning, companies cannot control the entire market.

Then the principle of the second marketing strategy is to choose a specific pattern of market concentration that will give the company the maximum opportunity to get a strong position. In other words the company must choose the market segment that can generate the most sales and profits; c) targeting, is a strategy of entering the market segment that is targeted for sale; d) Marketing mix strategy, a collection of variables that companies can use to influence consumer responses. Variables that can influence buyers are variables related to product, price, place, and promotion (4P); and e) Timing strategy, determining the right time to market the product is something that needs to be considered. Although the company sees a good opportunity. First, good production must be prepared.

\section{Community Perception}

Perception is a global observation, not yet accompanied by awareness, while the subject and object are not yet distinguished from one another (there is only a process that has a response) (Kartono, 1984: 77). Whereas according to Walgito (1994: 53) perception is organizing, interpreting, towards stimuli received by organisms or individuals so that it is an integrated activity within oneself.

According to Siagian (1995: 101) The process of perception through three processes, namely physical processes, physiological processes and psychological processes. Physical processes in the form of objects give rise to stimuli, then stimuli affect the senses or receptors. The physiological process is in the form of a stimulus received by the senses which is passed on by the sensory nerve to the brain. While psychological processes in the form of processes in the brain so that individuals realize the stimulus received. Factors that affect perception, consist of: a) the self concerned. When someone sees and tries to give an interpretation of what is seen. Individual characteristics that influence include attitudes, motives, interests, experiences and expectations, b) target perceptions that may be people, objects or events. This goal influences perception, c) situation factors. Perception must be seen contextually which means that in which situation the perception arises it needs to get attention. The situation is a factor that plays a role in fostering perception.

Perception in the process is influenced by several factors that make the process of perception grow. According to Sarwono (2003: 46) that differences in perception can be caused by things as follows: 1) Attention, usually we do not win all the stimuli that are around us at once, but we focus our attention on an object or two objects only. The difference in focus between one person and another, causes different perceptions between them; 2) Set. Set is a person's hope for stimuli that will arise. For example in a runner who is ready on the "star" line there is a set that will sound the gun when he has to start running, different sets can cause 
different perceptions; 3) Needs. Momentary and permanent needs in a person, that person will affect perception. Thus different needs will cause different perceptions; 4) Value system. The value system that applies in a society also influences perception. An experiment in the United States (Bruner and Godman, 1947, Carter and Schooler, 1949) shows that children from poor families perceive coins as larger than their actual size. This symptom was not found in children who came from wealthy families; and 5) Personality traits. Personality traits will also affect perceptions such as two people who work in the same office under the supervisor of a boss, shy people and people with high self-confidence will be different in perceiving their superiors.

\section{Conceptual Framework}

Based on previous studies, the relationship between marketing strategy variables can influence the decision to choose partially based on research conducted by Rusno (2008) where the marketing mix consisting of products, prices, promotions, places, people, processes and physical environment has an influence positive and significant decision to choose.

Besides Yang, X (2016), where the results of the study say that in providing a perception of taking a decision in education is indeed very important, because the perception itself will greatly influence attitudes in making a decision.

Decision to choose (Y), built with dimensions and indicators and / or indicators: 1) Knowledge; 2) Attitude; 3) Personality; 4) Lifestyle; and 5) Demographics. Marketing Strategy (X1) is built with dimensions and / or indicators: 1) Product; 2) Price; 3) Place; and 4) Promotion. Perception (X2) is built with dimensions and/or indicators: 1) Attention; 2) Needs; 3) Value system; and 4) Personality.

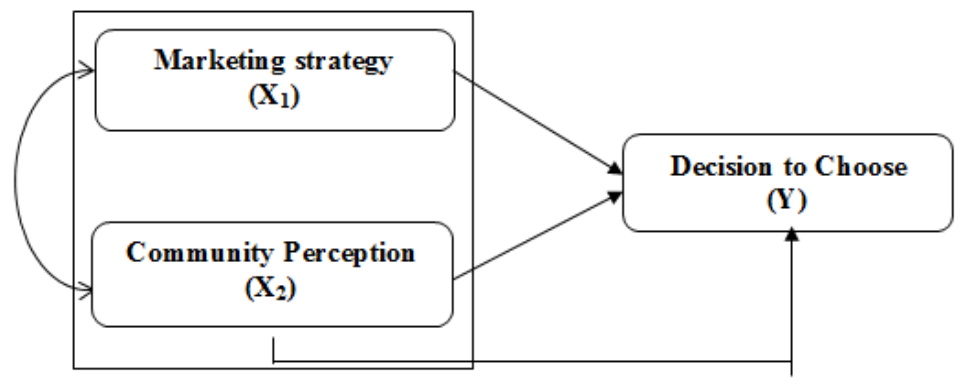

Figure 1. Conceptual Framework

Based on the research objectives and theoretical review, the research hypothesis is:

1) Marketing strategy influences the decision to choose;

2) Public perception influences the decision to vote; and

3) Marketing strategies and people's perceptions influence the decision to choose.

\section{RESEARCH METHODS}

This research was conducted using an associative quantitative approach with survey methods and using path analysis techniques. The path analysis developed first in 1920 by a geneticist (Sewall Wright) was used to analyze the pattern of relationships between variables in order to determine the direct or indirect effects of a set of (exogenous) independent variables (endogenous). (Riduwan and Kuncoro, 2013). 
The population in this study was the community that sent their children to the Private Islamic Madrasah in Jambi Province which represented 3 regions with 178 people. Before the analysis, a questionnaire instrument test was carried out with validity and reliability test and analysis requirements test with normality, homogeneity and linearity of the research variables.

Path analysis is one of the analytical tools developed by (Dillon and Goldstein in Ali, $\mathrm{H}$ and Limakrisna, N., 2013: 137). Wright developed a method to determine the direct and indirect effects of a variable, where there are variables that exert influence (exogenous variables) and variables affected (endogenous variables).

\section{FINDINGS AND DISCUSSION}

\section{Description of Research Data}

Descriptive statistics used are measures of central symptoms which include the highest score, lowest score, mean, mode, median, standard deviation and sample variance. In addition to the size of the central symptom and the distribution of data, the frequency distribution table and histogram graph are also used. The results of descriptive statistics in the study using the SPSS 21.0 tool as follows:

Table 1. Descriptive Statistics of Research Variables

\begin{tabular}{lrrrr}
\hline & $\begin{array}{c}\text { X1_Strategy } \\
\text { Marketing }\end{array}$ & $\begin{array}{c}\text { X2_Perception } \\
\text { Society }\end{array}$ & $\begin{array}{l}\text { Y Decision to } \\
\text { Choose }\end{array}$ \\
\hline \multirow{2}{*}{\begin{tabular}{l} 
Valid \\
\cline { 2 - 5 }
\end{tabular}} & $\begin{array}{l}\text { Missin } \\
\mathrm{g}\end{array}$ & 0 & 148 & 148 \\
\hline Mean & 115.77 & 129.30 & 128.58 \\
\hline $\begin{array}{l}\text { Std. Error } \\
\text { Mean }\end{array}$ & 1.0739 & 1.0396 & 1.1348 \\
\hline Median & & & \\
\hline Mode & 116.74 & 129.97 & 129.88 \\
\hline Std. Deviation & 117.01 & 130.93 & 131.25 \\
\hline Variance & 12.928 & 12.692 & 14.002 \\
\hline Range & 167.13 & 161.0869 & 196.06 \\
\hline Minimum & 56.0 & 55.0 & 60.0 \\
\hline Maximum & 86.0 & 100.0 & 96.0 \\
\hline Sum & 141.0 & 154.0 & 155.0 \\
\hline
\end{tabular}

a. Multiple modes exist. The smallest value is shown Source: Output SPSS 21.0

Table 2. Variable Frequency Distribution Decision to Choose (Y)

\begin{tabular}{ccccc}
\hline No & $\begin{array}{c}\text { Interval } \\
\text { Class }\end{array}$ & Frequency & $\begin{array}{c}\text { Relative } \\
\text { Frequency } \\
(\boldsymbol{\%})\end{array}$ & $\begin{array}{c}\text { Cumulative } \\
\text { Frequency }\end{array}$ \\
\hline 1 & $96-103$ & 8 & 5.41 & 8 \\
\hline 2 & $104-111$ & 12 & 8.11 & 20 \\
\hline 3 & $112-119$ & 16 & 10.81 & 36 \\
\hline 4 & $120-127$ & 24 & 16.22 & 60 \\
\hline
\end{tabular}




\begin{tabular}{|c|c|c|c|c|}
\hline 5 & $128-135$ & 47 & 31.76 & 107 \\
\hline 6 & $136-143$ & 21 & 14.19 & 128 \\
\hline 7 & $144-151$ & 11 & 7.43 & 139 \\
\hline 8 & $152-159$ & 9 & 6.08 & 148 \\
\hline & Total & 148 & 100 & \\
\hline
\end{tabular}

Based on Table 2 above the mode value, the median and mean are located in the fifth interval class 128 - 135. In addition, the number of respondents who get the highest score and the lowest score is balanced so that the data tends to be normally distributed. The table above also illustrates that the frequency distribution of the decision decision variable is a symmetrical curve. This is indicated by the mode score, the median and the mean located in the fifth interval class. Where the frequency distribution table for the decision to choose above also shows that there were $47(31.76 \%)$ respondents in the average group, $21(14.19 \%)$ respondents were above the average group and $24(16.22 \%)$. ) respondents are below average.

Table 3. Variable Frequency Distribution of Marketing Strategies $\left(\mathrm{X}_{1}\right)$

\begin{tabular}{|c|c|c|c|c|}
\hline No & $\begin{array}{c}\text { Interval } \\
\text { Class }\end{array}$ & Frequency & $\begin{array}{c}\text { Relative } \\
\text { Frequency } \\
(\%)\end{array}$ & $\begin{array}{l}\text { Cumulative } \\
\text { Frequency }\end{array}$ \\
\hline 1 & $86-92$ & 8 & 5.41 & 8 \\
\hline 2 & $93-99$ & 11 & 7.43 & 19 \\
\hline 3 & $100-106$ & 14 & 9.46 & 33 \\
\hline 4 & $107-113$ & 24 & 16.22 & 57 \\
\hline 5 & $114-120$ & 42 & 28.38 & 99 \\
\hline 6 & $121-127$ & 19 & 12.84 & 118 \\
\hline 7 & $128-134$ & 18 & 12.16 & 136 \\
\hline 8 & $135-141$ & 12 & 8.11 & 148 \\
\hline \multicolumn{2}{|r|}{ Jumlah } & 148 & 100 & \\
\hline
\end{tabular}

Based on Table 3 above the mode, median and mean values lie in the fifth interval class 114-120. In addition, the number of respondents who obtained the highest score and the lowest score was balanced so that the data had a tendency to distribute normally. The table above also illustrates that the frequency distribution of marketing strategy variables is symmetrical curve. This is shown by the mode, median and mean scores located in the fifth interval class 114-120. Where the frequency distribution table of the marketing strategy above also shows that there are $42(28.38 \%)$ respondents in the average group, 19 ( $12.84 \%$ of respondents were above the average group and $24(16.22 \%)$ respondents were below the average.

Table 4. Frequency Distribution of Community Perception Variables $\left(\mathrm{X}_{2}\right)$

\begin{tabular}{ccccc}
\hline No & $\begin{array}{c}\text { Interval } \\
\text { Class }\end{array}$ & Frequency & $\begin{array}{l}\text { Relative } \\
\text { Frequency } \\
(\boldsymbol{\%})\end{array}$ & $\begin{array}{l}\text { Cumulative } \\
\text { Frequency }\end{array}$ \\
\hline 1 & $100-106$ & 9 & 6.08 & 9 \\
\hline 2 & $107-113$ & 9 & 6.08 & 18 \\
\hline
\end{tabular}




\begin{tabular}{|c|c|c|c|c|}
\hline 3 & $114-120$ & 16 & 10.81 & 34 \\
\hline 4 & $121-127$ & 28 & 18.92 & 62 \\
\hline 5 & $128-134$ & 34 & 22.97 & 96 \\
\hline 6 & $135-141$ & 26 & 17.57 & 122 \\
\hline 7 & $142-148$ & 17 & 11.49 & 139 \\
\hline 8 & $149-155$ & 9 & 6.08 & 148 \\
\hline & Jumlah & 148 & 100 & \\
\hline
\end{tabular}

Based on Table 4 above the mode, median, and mean values lie in the fifth interval class 128 - 134. In addition, the number of respondents who obtained the highest score and the lowest score was balanced so that the data had a tendency to distribute normally. The table above also illustrates that the frequency distribution of the community perception variable is a symmetrical curve. This is indicated by the mode and median scores that are close to the average. Where the table of distribution of frequency of public perception above also shows that there are 34 $(22.97 \%)$ respondents in the average group, 26 (17.57\%) respondents are above the average group and $28(18.92 \%)$ below average respondent.

\section{Test analysis requirements}

Before proceeding to hypothesis testing, it must first go through the calculation of analysis requirements. Testing requirements analysis used consists of three types, namely the normality test and homogeneity test. The following will be explained one by one the results of tests conducted.

Normality test. Normality test aims to determine the distribution of errors obtained in normal distribution or not. The normality test conducted in research using the Chi Square test. The normality test results above are summarized in the following Table 5.

Table 5. Chi Squared Normality Test Results

\begin{tabular}{clccl}
\hline No & \multicolumn{1}{c}{ Variable } & $\boldsymbol{x}^{2}$ count & $\boldsymbol{x}^{2}$ table & Information \\
\hline 1 & Decision to Choose $(\mathrm{Y})$ & 9,94 & 14,067 & Normal distribution \\
\hline 2 & Marketing strategy $\left(\mathrm{X}_{1}\right)$ & 12,36 & 14,067 & Normal distribution \\
\hline 3 & Community Perception $\left(\mathrm{X}_{2}\right)$ & 8,92 & 14,067 & Normal distribution \\
\hline Normal Requirements $\boldsymbol{x}^{2}{ }_{\text {count }}<\boldsymbol{x}^{2}{ }_{\text {table }}$ \\
\hline
\end{tabular}

Based on the results of the calculation of the normality test X1 obtained x 2 count of 12.36 , the normality test $\mathrm{X} 2$ obtained $\mathrm{x} 2$ count of 8.92 , and the normality test $\mathrm{Y}$ obtained by $\mathrm{x} 2$ count of 9.94. From the results of the calculation of the three variables above, the value of $x 2$ calculated which is smaller than $\mathrm{x} 2$ table shows that all variables are declared to be normally distributed, and can be continued for further research.

Homogenity test. The homogeneity test aims to find out whether the variant is homogeneous or not. The homogeneity testing criteria is accept $\mathrm{H}_{1}$ if $\mathrm{X}_{2}$ counts the value smaller than $\mathrm{X}_{2}$ table and accept $\mathrm{H}_{0}$ if $\mathrm{X} 2$ counts the value is greater $\mathrm{X}_{2}$ table with a significance level of $\alpha=0.05$. The results of the homogeneity test in this study are summarized in the following table: 
Table 6. Homogeneity Variance Test Results

\begin{tabular}{|c|c|c|c|c|c|c|}
\hline \multirow[b]{2}{*}{ No } & \multirow[b]{2}{*}{ Error } & \multirow{2}{*}{$\begin{array}{c}\text { Number } \\
\text { of } \\
\text { Samples }\end{array}$} & \multirow[b]{2}{*}{ Dk } & \multicolumn{2}{|c|}{$\mathbf{X}^{2}(\mathbf{0 , 0 5})$} & \multirow[b]{2}{*}{ Conclusion } \\
\hline & & & & $X^{2}$ count & $\mathbf{X}^{2}$ table & \\
\hline 1 & $Y$ is grouped on $X_{1}$ & 148 & 115 & 24,803 & 91,242 & Homogen \\
\hline 2 & $Y$ is grouped on $X_{2}$ & 148 & 111 & 17,238 & 87,681 & Homogen \\
\hline Hon & ogeneous precondit & tung $<x_{\text {tabel }}^{2}$ & & & & \\
\hline
\end{tabular}

Based on the results of the homogeneity test calculations, the calculated $\mathrm{X}_{\text {value }}^{2}$ is smaller than the $\mathrm{X}_{\text {table }}^{2}$ so $\mathrm{H}_{1}$ is accepted and it is concluded that all errors in this study indicate a homogeneous variance.

\section{Research result}

The results of this study are summarized as Table 7 below with the coefficient of marketing strategy variables (X1) and public perception (X2) are (Pyx $1=0.390$ and $\mathrm{Pyx} 2=$ 0.491 ) and the correlation between variables $\mathrm{X} 1$ and $\mathrm{X} 2$ is 0.801 which can be presented as shown in Figure 2 in below this:

Table 7. Coefficients regression Coefficients ${ }^{\mathrm{a}}$

\begin{tabular}{|c|c|c|c|c|c|}
\hline \multirow[t]{2}{*}{ Model } & \multicolumn{2}{|c|}{$\begin{array}{l}\text { Unstandardized } \\
\text { Coefficients }\end{array}$} & \multirow{2}{*}{$\begin{array}{c}\text { Standardized } \\
\text { Coefficients } \\
\text { Beta }\end{array}$} & \multirow[t]{2}{*}{$\mathrm{t}$} & \multirow[t]{2}{*}{ Sig. } \\
\hline & $\mathrm{B}$ & Std. Error & & & \\
\hline (Constant) & 12.041 & 6.431 & & 1.872 & .063 \\
\hline $\mathrm{X} 1 \_$MarketingStrategy & .412 & .080 & .390 & 5.136 & .000 \\
\hline X2_CommunityPerception & .536 & .083 & .491 & 6.467 & .000 \\
\hline
\end{tabular}

a. Dependent Variable: $Y_{-}$DecisiontoChoose

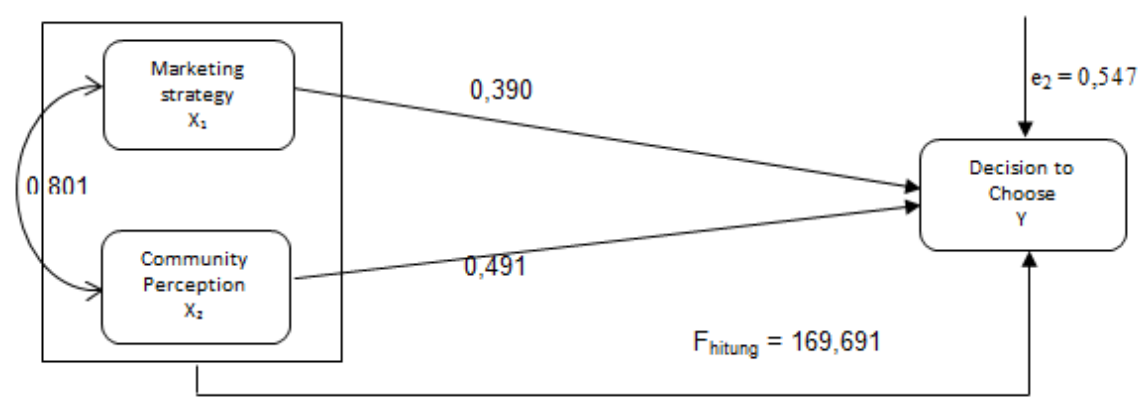

Figure 2. Path Analysis Structure Results

From the above table the path analysis coefficient results are obtained: $\mathrm{Y}=$ pyx1.X1 + pyx2. $\mathrm{X} 2+\mathrm{e}=0.390 . \mathrm{X} 1+0.491 . \mathrm{X} 2+0.547$. The marketing strategy variable path coefficient value for the decision decision variable is 0.390 . The path coefficient value of the public 
perception variable on the decision decision variable is 0.491 . The coefficient is positive, meaning that the marketing strategy and public perception have a positive effect on the decision to choose.

Then to find out the total effect of marketing strategy variables and public perceptions of the decision to choose can be seen from the summary table, as follows:

Table 8. Model summary

Model Summary

\begin{tabular}{lcccr}
\hline Model & R & R Square & Adjusted R Square & Std. Error of the Estimate \\
\hline 1 & $.837^{\text {a }}$ & .701 & .697 & 7.6053 \\
\hline a. Predictors: (Constant) & X2 CommunityPerception, X1 & MarketingStrategy
\end{tabular}

a. Predictors: (Constant), X2_CommunityPerception, X1_MarketingStrategy

Source: Output SPSS 21.0 for windows

$\mathrm{R}$ value of 0.837 shows a double correlation (marketing strategy and public perception) with the decision to choose. Taking into account the variation of the Adjusted R Square Value of 0.697 , it means that the magnitude of the role or contribution of the marketing strategy variable and public perception can explain the decision-making variable of $69.7 \%$. While the remaining $30.3 \%$ is influenced by other variables not included in this model.

\section{Partial Influence (t Test) and Simultaneous Effect (Test F)}

The partial effect testing aims to test whether each independent variable has a significant effect on the dependent variable partially with $\propto=0.05$ and acceptance or rejection of the hypothesis. Partial test ( $t$ test) to answer hypotheses one and two of this study.

Table 9. t Test Results (Partial)

\begin{tabular}{|c|c|c|c|}
\hline No & Independent Variable & $\mathrm{t}_{\text {count }}$ & Sig. \\
\hline 1 & Marketing Strategy $\left(\mathrm{X}_{1}\right)$ & 5,136 & 0.000 \\
\hline 2 & Community Perception $\left(\mathrm{X}_{2}\right)$ & 6,467 & 0.000 \\
\hline
\end{tabular}

From Table 9 above, the tcount value of leadership style variable is 5.136, because the value of $t_{\text {count }}>t_{\text {table }}(5.136>1,655)$, then partially the marketing strategy has an influence on the decision to choose. Therefore, $\mathrm{H}_{0}$ is rejected, meaning that partially there is a significant influence between the marketing strategy and the decision to choose. In addition, to test based on significance testing, it can be seen from the significance output of 0,000 , because the significance level is more than $<0.05(0.000<0.05)$, so it can be concluded that the marketing strategy influences the decision to choose the madrasa. Thus, the first hypothesis is accepted. From Table 9 above, the value of the leadership style variable is 5.136, because the value of $\mathrm{t}_{\text {count }}$ $>t_{\text {table }}(5.136>1.655)$, then the marketing strategy partially has an influence on the decision to choose. Therefore, $\mathrm{H}_{0}$ is rejected, meaning that partially there is a significant influence between the marketing strategy and the decision to choose. Besides that, to conduct a test based on significance testing, it can be seen from the significance output of 0,000 , because the number of significance level is more $<0.05(0.000<0.05)$, it can be concluded that the marketing strategy influences the decision to choose madrasas. Thus the first hypothesis is accepted. 
The $t_{\text {count }}$ value of the public perception variable is 6,467 , because the value of $t_{\text {count }}>t$ $(6,467>1,655)$, then partially the public perception has an influence on the decision to vote. Therefore, $\mathrm{H}_{0}$ is rejected, meaning that partially there is a significant influence between people's perceptions and the decision to choose. Besides that, to conduct a test based on significance testing, it can be seen from the significance output of 0,000 , because the number of significance level is more $<0.05(0.000<0.05)$, it can be concluded that the public perception influences the decision to choose. This means that the second hypothesis is accepted.

To answer the third hypothesis that marketing strategies and public perceptions influence the decision to choose simultaneously can be seen from Table 10 below.

Table 10. Simultaneous F test results

\begin{tabular}{llrrrrr}
\multicolumn{7}{c}{ ANOVA $^{\mathbf{a}}$} \\
Model & & Sum of Squares & Df & Mean Square & F & \multicolumn{1}{c}{ Sig. } \\
\hline \multirow{3}{*}{1} & Regression & 19629.961 & 2 & 9814.980 & 169.691 & $.000^{\mathrm{b}}$ \\
\cline { 2 - 7 } & Residual & 8386.850 & 145 & 57.840 & & \\
\cline { 2 - 7 } & Total & 28016.811 & 147 & & & \\
\hline
\end{tabular}

a. Dependent Variable: $Y_{-}$DecisiontoChoose

b. Predictors: (Constant), X2_CommunityPerception, X1_ MarketingStrategy

Source: SPSS 21.0 for Windows output

From the Anova test or the $\mathrm{F}$ test as shown in Table 10, the $\mathrm{F}_{\text {count }}$ value obtained is 169,691 with a probability level of p-value of 0,000 , because the value of $F_{\text {count }}>\mathrm{F}(169,691>$ 3.06) so that it can be concluded that the null hypothesis $\left(\mathrm{H}_{0}\right)$ is rejected and alternative hypothesis $\left(\mathrm{H}_{1}\right)$ is accepted, meaning that there is a significant influence between marketing strategy and community perception together on the decision to vote. In addition, to test based on significance testing, it can be seen from the significance output of 0,000 , because the level of significance is far more $<0.05(0,000<0.05)$, so it can be concluded that the marketing strategy variable and public perception together influence the significant to the decision variable (Y). Thus the third hypothesis is accepted.

Meanwhile, to see the direct and indirect effects, can be seen in the following table:

Table 11. Summary of Path Coefficients

\begin{tabular}{cccccr}
\hline \multirow{2}{*}{ Variable } & Directl & \multicolumn{2}{c}{ Indirect } & Sub & \multirow{2}{*}{ Total } \\
\cline { 3 - 4 } & $\mathrm{y}$ & $\mathrm{X}_{1}$ & $\mathrm{X}_{2}$ & Total & \\
\hline Marketing Strategy $\left(\mathrm{X}_{1}\right)$ & 0,152 & & 0,153 & 0,153 & 0,305 \\
\hline Community Perception $\left(\mathrm{X}_{2}\right)$ & 0,241 & 0,153 & & 0,153 & 0,394 \\
\hline Influence $\mathrm{X}_{1}, \mathrm{X}_{2}$ & & & 0,697 \\
\hline Effect of other variables & 0,303 \\
\hline Source: Processed data from SPSS 21.0 for processed windows.
\end{tabular}

In line with the path analysis research method stated in the previous section, it is known from the table above that the total value of the influence of marketing strategies and people's perception of the decision to choose either directly or indirectly is 0.699 . This value explains the determination coefficient value of Adjusted R Square as seen in the results of the Adjusted R Square test in Table 9. Which explains the magnitude of the role or contribution of the marketing strategy variables and public perceptions of being able to explain the decision decision variable 
by $69.9 \%$. While the remaining $30.3 \%$ is influenced by other variables not included in this model.

\section{1) Marketing Strategies for Choosing Decisions}

Marketing strategies have a direct effect on the decision to choose significantly. This finding indicates that if a leader is able to implement a marketing strategy consisting of product, price, place, and promotion well, it will be able to improve consumer decisions in choosing an islamic school.

The results of this study show the same results as the research conducted by Supriyani (2016) which suggests that marketing mix strategies have an influence on students' decisions in choosing Tuban Islamic Junior High School. In addition, Rusno (2008) also revealed that marketing strategy has a positive and significant influence on the decision to choose. The results of this study reveal that if the leader is able to implement a marketing strategy that consists of a product, price, place, and promotion well, this will be followed also by the decision of students or parents in choosing Islamic school.

Marketing does sound strange if applied to the education sector because education is a nonprofit sector. But schools need to do marketing. According to Wijaya (2008: 42) marketing is said to be important because of various considerations. First, as a nonprofit institution engaged in educational services, for any level, we need to convince the public and customers (students, parents, and other relevant parties) that the educational institutions we manage still exist. Second, we need to convince people and customers that the services we provide are really relevant to their needs. Third, we need to do marketing activities so that the types and types of educational services we do can be widely known and understood by the public, especially customers, Fourth, so that the existence of educational institutions that we manage is not abandoned by the community and potential customers.

One of the marketing strategies that can be used by schools is the marketing mix strategy. The marketing mix according to Lupiyoadi and Hamdani (2006: 70) is a tool for marketers that consists of various elements of a marketing program that need to be considered so that the implementation of the marketing strategy set goes successfully. Marketing mix elements in the service sector include 7P, namely product, Price, promotion, place, People (HR) or educators and education available, Physical evidence or facilities and infrastructure, and the process or management of learning services provided. In this study only limited to four elements of the marketing mix, namely product, price, location, and physical evidence.

\section{2) Community Perception of Decisions to Choose}

Persepsi masyarakat berpengaruh langsung terhadap keputusan memilih. Temuan ini mengindikasikan jika sekolah mampu membangun persepsi masyarakat yang baik berupa perhatian, kebutuhan, sistem dan kepribadian sekolah, maka akan di ikuti pula dengan keputusan masyarakat dalam memilih Islamic school.

The results of this study show the same results as the research conducted by Yang, $\mathrm{X}$ (2016), where the results of the study prove that public perceptions have a significant effect on voting decisions and are the variables that have a dominant influence on voting decisions.

Perception has a strong influence on consumers. Perception is often a benchmark for consumers to forgive a manufacturer's fault or not. The better the perception, the easier it is for 
consumers to forgive the mistakes that occur. The service phase measures how much satisfaction and decision to buy, if there is a disappointing service stage, then all services will be considered bad, and vice versa. The service situation is determined by the service, the service process, the physical scope in which the service is provided (Andini, N., 2010).

\section{3) Marketing Strategies and Public Perceptions of Choosing Decisions}

The results of the hypothesis test found that marketing strategies and people's perceptions influence the decision to choose. The consumer purchasing decision process is a sequence of events that starts from the introduction of needs, then searches for information on those needs, after that evaluates alternatives, makes purchasing decisions, and after that ends with behavior after making a purchase. Therefore, the marketing mix strategy becomes very important because the marketing mix consisting of these elements will influence each other so that if one of the elements is incorrect, it will affect the marketing strategy that will be carried out (Kurniawati, D., 2013).

The research related to the decision to vote was conducted by Supriyani (2016), which explained that the product, price, location and promotion simultaneously had an influence on the students' decision in choosing Madrasah Aliyah Negeri Tuban. While the results of research Kurniawati, D (2013) explained that the marketing mix which includes: products (study programs), prices (tuition fees), promotions, locations, processes, people and services both simultaneously have an influence on the student's decision to choose Widya Mandala Catholic University Madiun Then Andini, N (2010) explained that perceptions in the form of facilities, price, quality and location had a positive and significant influence on parents' decisions in choosing educational services at SDIT Bina Insani Semarang.

\section{CONCLUSION AND SUGGESTION}

\section{Conclusion}

Based on the results and discussion, the conclusions of this study are:

1) The marketing strategy has a positive and significant effect on the decision to choose. The better the marketing strategy, the better the community's decision to choose an Islamic school;

2) perception has a positive and significant influence on decision to vote. The better the community's perception of a service, the better the community's decision to choose an Islamic school;

3) marketing strategies and community perceptions have a positive and significant effect on the decision to choose. The better marketing strategy and public perception of a product or service offered, the easier it will be for the community to make decisions about choosing an Islamic school..

\section{Suggestion}

Based on data analysis, the process of statistical calculations, testing of empirical research models and discussion of the results of studies conducted, several suggestions are given as follows:

1) It is expected that the head of a Private Islamic Junior High School in Jambi Province can improve the marketing strategy in order to increase the input of each Private Islamic Junior High School; 
2) It is expected that the supervisors, supervisors and even those who have an interest in the successful management of the Islamic Junior High School in Jambi Province are expected in the future. It is expected to be able to encourage and foster so that the community is interested in sending their children to a private Islamic Junior High School in Jambi Province; and

3) It is expected that the Ministry of Religion of the City / Regency and other interested parties including practitioners can pay attention to the development and progress of Private Islamic Junior High Schools.

\section{REFERENCE}

Ali, H dan Limakrisna, N. (2013). Research Methodology. Edisi 1, Cet. 1. Yogyakarta: Deepublish.

Alma, B. (2003). Pemasaran Stratejik Jasa Pendidikan. Bandung: Alfabeta.

Andini, N. (2010). Analisis Pengaruh Persepsi Terhadap Keputusan Orang Tua Murid Memilih Jasa Pendidikan di SDIT Bina Insani Semarang. Jurnal Manajemen dan Bisnis Universitas Diponegoro, Vol. 3, No. 1.

Dagun, M.S. (2006). Kamus Besar Ilmu Pengetahuan. Jakarta: Lembaga Pengkajian Kebudayaan Nusantara (LPKN).

Kartono, K. (1984). Psikologi Umum, Alumni bandung.

Kotler, P. (2003). Strategic Marketing for Educational Institusional. Prentice Hall.

Kurniawati, D. (2013). Pengaruh Strategi Bauran Pemasaran Terhadap Keputusan Mahasiswa Memilij Universitas Katolik Widya Mandala Madiun. Widya Warta, No. 1.

Lupiyoadi, R dan Hamdani, A. (2006). Manajemen Pemasaran Jasa, Edisi 2. Jakarta:Salemba Empat.

Machalli, I dkk. (2016). The Handbook of Education management Teori dan Praktek Pengelolaan Sekolah/Madrasah di Indonesia.

Maskan, M dkk. (2014). Persepsi Masyarakat Terhadap Kualitas Pelayanan di Terminal Arjosari Kota malang, Jurnal Bisnis, Manajemen \& Perbankan, Vol. 1, No. 1.

Mulyadi. (2011). Perilaku Konsumen dalam Perspektif Kewirausahawan. Jakarta: Alfabeta.

Mulyasa. (2011). Manajemen Berbasis Sekolah, Konsep, Strategi, dan Implementasi. Bandung: Remaja Rosdakarya.

Riduwan dan Kuncoro E.A. (2013). Cara menggunakan dan memakai Path Analysis (Analisis Jalur). Bandung: Alfabeta.

Rusno (2008). Pengaruh karakteritik Individu Lingkungan dan Bauran Karakteristik Individu Lingkungan dan Bauran Pemasaran PTS Terhadap keputusan Mahasiswa dalam Melanjutkan Study Padab PTS di Kota Malang, Jurnal Ekonomi MODERNISASI Fakultas Ekonomi-Universitas Kanjuruhan Malang, 2008. Hal. 7.

Sarwono, S.W. (2003). Pengantar Umum Psikologi. Jakarta: Bulan Bintang.

Siagian, S.P. (1995). Teori Motivasi dan Aplikasinya. Jakarta: Rineka Cipta

Siswanto, H.B. (2012). Pengantar manajemen. Jakarta: Bumi Aksara.

Sudaryono, (2016). Manajemen Pemasaran, Teori \& Implementasi. Yogyakarta: CV Andi Ofset. Supriyani. (2016). Pengaruh Strategi Bauran Pemasaran Terhadap Keputusan Siswa Dalam Memilih Madrasah Aliyah Negeri Tuban. Jurnal Dinamika Manajemen Pendidikan, Vol. 1, No. 1.

Terry, G.R. (2012). Prinsip-Prinsip Manajemen, Alih Bahasa J. Smith. D.F.M. Jakarta: Bumi Aksara.

Walgito, B. (1994). Pengantar Psikologi Umum. Yogyakarta: Andi Offsed. 
Wijaya, D. (2008). Pemasaran Jasa Pendidikan sebagai Upaya Untuk Meningkatkan Daya Saing Sekolah. Jurnal pendidikan Penabur Nomor 11/Tahun ke-7.Jakarta: BPK Penabur (online).

Yang, X. (2016). Education Marketing Research. Theoretical Economics Letters 